\title{
Criminal Law Administration: The Zero Hour Was Coming
}

\author{
Monrad G. Paulsen*
}

When ... [the Supreme Court] ... made the exclusionary rule mandatory in all states, it could hardly have taken anyone by surprise.... the hours had been successively striking that the zero hour was coming. $\dagger$

$\mathbf{R}$ OGER TRAYNor has not left for conjecture his answer to the question, "What should judges do?" His pubhished lectures address themselves to various aspects of the question. He has put his ideas to work in carefully written opinions including those which relate to the administration of criminal justice. ${ }^{1}$

Chief Justice Traynor would modernize the law. "Whatever our admiration for ancient arts, few of us would turn the clock back to live out what museums preserve," he told a Columbia University Law School audience in 1958. "The main preoccupation of [the] . . law must be with the future."3

Strong sentiments about the pressing need for law improvement are not likely to feed a conservative theory of judicial self-restraint. It is true that Chief Justice Traynor does envy the legislature and its task. Lawmakers can take a broad view of a total problem, break sharply with the past and, at the same time, avoid the costly and confusing pattern of piecemeal litigation. Legislators hold the initiative in the struggle for law reform. All this is true, but it is not all. The judges, too, have forwardlooking work to do. Chief Justice Traynor has decried timid judges and slothful lawyers. "The growth of the law, far from being unduly accelerated by judicial boldness, is unduly hainpered by a judicial lethargy that masks itself as judicial dignity with the tacit approval of an equally lethargic bar. ... We have had a plethora of copycats."4

* A.B. 1940, J.D. 1942, University of Chicago. Professor of Law, Columbia University.

† Traynor, Mapp v. Ohio at Large in The Fifty States, 1962 DukE L.J. 319, 324.

I See especially Traynor, Comment on Courts and Law Making, in LEGAL Instrrutuons Todax AND Tosrorrow 48 (Paulsen ed. 1959); Traynor, Some Open Questions on the Work of Stale Appellate Courts, 24 U. CrI. L. REv. 211 (1957); Traynor, Badlands in an Appel late Judge's Realm of Reason, 7 UTAI L. REv. 157 (1960); Traynor, La Rude Vita, La Dolce Giustizia; Or Hard Cases Can Make Good Law, 29 U. CHI. L. Rev. 223 (1962); Traynor, Better Days in Court for a New Day's Problems, 17 Vand. L. Rev. 109 (1963).

2 Traynor, Comment on Courts and Law Making, in Legar INsTitutrons Today aND TOMORRow 48 (Paulsen ed. 1959).

$3 I d$. at 50 .

4 Id. at 52-53. 


\section{I \\ People v. Cahan}

The Chief Justice is no copycat. He has written with wisdom on a clean slate time and time again. People v. Cahan, ${ }^{5}$ a 1955 case in which the California Supreme Court adopted the rule excluding illegally obtained evidence from criminal trials, and the several later Traynor opinions which elaborated the exclusionary rule and the principles governing police conduct, provide an excellent set of examples.

Cahan reversed many years of California experience. The older practice of admitting illegally obtained evidence had been defended by many of the most able judges and scholars including the late Dean John Wigmore. Indeed, in 1942 Chief Justice Traynor himself had written one of the leading opimions rejecting the exclusionary evidence rule for California. ${ }^{6}$ He saw no reason to disregard relevant evidence in a factfinding proceeding. "The defendant may have civil and criminal remedies against the officers for their illegal acts." Neither the Federal Constitution nor the California constitution required illegally obtained evidence to be excluded. The protection of privacy from the unreasonable searches and seizures of officialdom may be a fundamental right guaranteed by the fourteenth amendment against intrusions by state officers, but, even so, the Chief Justice saw no constitutional barrier to the use of tainted evidence.

It does not necessarily follow ... that the use in a court of law of evidence thus obtained is so contrary to fundamental principles of liberty and justice as to constitute a denial of due process of law. A criminal trial does not constitute a denial of due process of law so long as it is fair and impartial.... The fact that an officer acted improperly in obtaining evidence presented at the trial in no way precludes the court from rendering a fair and impartial judgment. ${ }^{8}$

What had happened between 1942 and 1955? Had the facts changed or the law changed or the judge changed? Perhaps a little of each. The facts of life are constantly on the move. The Supreme Court of the United States had given a strong warning to the states that they must either adopt the exclusionary rule or take some other effective step to curb pohice lawlessness. ${ }^{9}$ Speaking of himself, Justice Traynor has admit-

544 Cal. 2d 434, 282 P.2d 905 (1955).

6 People v. Gonzales, 20 Cal. 2d 165, 124 P.2d 44 (1942).

TId. at 169,124 P.2d at 46 .

8 Id. at $170,124 \mathrm{P} .2 \mathrm{~d}$ at 47.

${ }^{9}$ See the discussion in Traynor, Mapp v. Ohio at Large in The Fifty States, 1962 Dure L.J. $319,324$. 
ted that, "In 1942 clear academic postulates were not as yet unclouded by long judicial experience."10

Whatever effect these changes may have had, another event of high importance had occurred by the spring of 1955. An aspect of reality had become highly visible to the Justices of the Supreme Court of California. In several cities throughout the state, notably in Los Angeles, the police were paying too little attention to the constitutional protection against illegal searches and seizures. For example, in Cahan's case, hidden microphones had been placed in homes on two occasions by illegal breaking and entering on the part of officers. "In addition," wrote Justice Traynor, "there was a mass of evidence obtained by numerous forcible entries and seizures without warrants." 11 Most of the incriminatory evidence against Cahan, he went on to say, "was obtained by officers of the Los Angeles Police Department, in flagrant violation of the United States Constitution, fourth and fourteenth amendments, the Cahifornia constitution, art. 1, section 19, and state and federal statutes."12 The violations were not the work of inexperienced policemen, ill-informed about the constitutional law, but had been undertaken after securing permission of the Los Angeles Chief of Police.

Another example, this time from San Francisco, is offered by the facts in People v. Berger, ${ }^{13}$ a case decided on the same day as Cahan. The defendant in Berger was away from his place of business when a representative of the district attorney entered, armed with a warrant which placed no restrictions on the area to be searched or the things to be seized. Brushing aside an office inanager's request to wait for the defendant, the investigator replied, "Well, while we are waiting liere there is no use wasting the time, we will just start looking into things and getting them ready to take what we want."14 The publislied opmion continues to recount the event. "For five hours the investigator, the police, and an assistant district attorney ransacked defendant's files, desks, and wastebaskets. The investigator testified: 'We were looking around for evidence of the commission of the alleged crime ... anything that slowed the commission of the crime charged.' They read letters, cards, and records, and, according to the investigator, seized 'thousands; tens of thousands' of cards, letters, files, and other documents, 'that seemed relevant to the commission of the crime.' Over defendant's protests, they loaded the seized papers on a van and took thein to the District Attorney's office. 115

10 Id. at 321.

11 People v. Cahan, 44 Cal. 2d 434, 437, 282 P.2d 905, 906 (1955).

12 Id. at 436,282 P.2d at 906.

1344 Cal. 2d 459, 282 P.2d 509 (1955).

14 Id. at $460,282 \mathrm{P} .2 \mathrm{~d}$ at 510 .

15 Ibid. 
- The facts of these and other cases established the facts for history. "Without fear of criminal punishment or other discipline, law enforcement officers, sworn to support the Constitution of the United States and the Constitution of California, frankly admit their deliberate, flagrant acts in violation of both Constitutions and the laws enacted thereunder. It is clearly apparent from their testimony that they casually regard such acts as nothing more than the performance of their ordinary duties for which the city employs and pays them." ${ }^{16}$ Again, the violations were not the work of a blundering constable; the invasions of privacy lad been planned at the highest levels of police leadership. The remedies for unconstitutional police action were ineffective; they had "completely failed to secure compliance with the constitutional provisions." "17 The reception of illegally obtained evidence was a positive encouragement to further violations of law. "[T] he success of the lawless venture depends entirely on the court's lending its aid by allowing the evidence to be introduced."18

The difference between 1942 and 1955 was simply this: In 1942 Chief Justice Traynor believed that police self-restraint or the standard legal remedies would generally confine police action within the boundaries of constitutional guarantees; by 1955 it was painfully clear that such a belief could no longer be sustained. No attempt was made to distinguish the facts of Cahan from those in earlier cases. The facts perceived in 1955 had slown the rule permitting the use of illegally obtained evidence to be unsatisfactory. The action taken was uncompromising: "People v. Le Doux ... . People v. Mayen . . . , and the cases based thereon are therefore overruled."19

The Chief Justice has no patience with the technique of overruling precedents by distinguishing them away. "There are, of course, precedents," Chief Justice Traynor has said, "originally so unsatisfactory or grown so unsatisfactory with time as to deserve liquidation." When such precedents are found, the courts should "bring about their demise." All of us should welcome "frank renunciation." The reality of change is better than a mask of certainty which conceals novement. "It must be cold comfort to bewildered counsel to ruminate that the precedent on

16 People v. Cahan, 44 Cal. 2d 434, 282 P.2d 905 (1955). In a lecture delivered at Duke University, the Justice discussed the significance of the steady stream of cases demonstrating illegal police conduct. "It was the cumulative effect of such routine that led us at last in the case of People v. Cahan to reject illegally obtained evidence." Traynor, Mapp v. Ohio at Large in The Fifty States, 1962 DUKE L.J. 319, 322.

17 People v. Cahan, 44 Cal. 2d 434, 445, 282 P.2d 905, 911 (1955).

$18 \mathrm{Id}$. at $445,282 \mathrm{P} .2 \mathrm{~d}$ at 912.

19 Id. at $445,282 \mathrm{P} .2 \mathrm{~d}$ at 911 .

20 Traynor, La Rude Vita, La Dolce Giustizia; Or Hard Cases Can Make Good Law, 29 U. CHI. L. REV. 223, 230 (1962). 
which he relied was never expressly overruled because it so patently needed to be."21

Justice Spence, dissenting in Cahan, argued that if reasons exist "for a change in the established policy of this state ... the Legislature rather than the courts, should make such change."22 Chief Justice Traynor made no direct reply. Perhaps he felt that the courts should put the situation to right because the courts themselves had encouraged the lawlessness by admitting illegal evidence. But there is another point as well. The Chief Justice surely envies the Legislature, but his envy does not emasculate the power of appellate judges. He has argued that judges must "come to understand the court's responsibility in terms not of power but of obligation. The danger is not that they will exceed their power but that they will fall short of their obligation.".28 In the first Leary lecture at the University of Utah, he put the point plamly. Appellate judges should rid themselves, "of the superstition that once the courts have allowed a precedent to live beyond its time they are bound to continue its social security indefinitely unless an impatient legislature steps in to decree otherwise. Such superstition invites two hazards. One is that the legislators will never rush to the execution. The other is that they will."24

Cahan is an example of the action which comes from Chief Justice Traynor's reflections about judging appeals. It is also a decision accompanied by an impressive opinion. The purpose of the rule of the older cases is fully explored. The arguments of scholars and judges in its support have seldom been stated more forcefully. In fact, the persuasive power of these arguments brings strength to the defense of the court's decision. The facts about poiice misconduct inust certainly be alarming if they call us to abandon a position that can be so strongly defended. Over and over again we are told "there is no other way." Courts encourage the police to disregard the Constitution if they permit the use of evidence taken in violation of it. No other remedy is effective. Constitutional provisions are not being enforced.

One may, of course, dispute the conclusion of Cahan. Maybe the exclusionary evidence rule has as little effect on the conduct of the police as the other remedies. The rule may create more problems than it solves. Yet the Cahan opinion, itself, is a great achievement. All voices are heard, and we are told why Reason chooses to follow one set of arguments rather than another.

21 Traynor, supra note 2, at 54 .

22 People v. Cahan, 44 Cal. 2d 434, 457, 282 P.2d 905, 919 (1955).

23 Traynor, Some Open Questions on the Work of State Appellate Courts, 24 U. CHr.

L. REv. 211, 224 (1957).

24 Traynor, Badlands in an Appellate Judge's Realm of Reason, 7 UTAH L. Rev. 157, 167 (1960). 


\section{II}

\section{THE SONS OF Cahan}

Like other states which had admitted evidence in criminal trials without regard to the method of obtaining it, California had almost no case law respecting the legality of arrests, searches and seizures. Actions seeking damages for false arrest or for trespass are infrequently brought. Criminal prosecutions against offending officers are all but completely unknown. On the other hand, the law reports in those states which had embraced the rule of exclusion before $M a p p v$. Ohio ${ }^{25}$ are filled with opinions testing police conduct. The defendant in every serious criminal case can easily litigate the lawfulness of an arrest or a search, and it is often in his interest to do so.

After Cahan, the California Supreme Court had to embark upon a "long overdue clarification of standards of reasonableness in law enforcement." Cahan had opened "the door to the development of workable rules governing searches and seizures and the issuance of warrants that will protect both the rights guaranteed by the Constitutional provisions and the interest of society in the suppression of crime."27

In this work of clarification, Chief Justice Traynor has been the California judge who has made the largest contribution. He has written more of the California court's opinions in relation to arrest and search than has any other judge. On February 24, 1956, nine cases involving search or seizure questions were decided by the Supreme Court of California. Justice Traynor wrote the opinion of the court in all nine. It is not only the quantity of the Chief Justice's work that is impressive but his judicial essays have created the landmarks. ${ }^{28}$

Obviously, as the California judges set out to develop "workable rules governing searches and seizures," the experience of the federal courts in the application of the exclusionary rule lay at hand. Yet the cases in the federal systein are far from satisfactory. A great many technical rules have been formulated which lack the underpinning of sound reason. The federal law of searches and seizures suffers, in Traynor's phrase, "from wooden association with tort and property concepts." In Cahan, Chief Justice Traynor declared his freedom from the authority of federal decisions. "If it appears that those decisions have developed needless refinements and distinctions, this court need not follow them." ${ }^{30}$ While

25367 U.S. 643 (1961).

26 Traynor, supra note 9, at 323.

27 People v. Cahan, 44 Cal. 2d 434, 451, 282 P.2d 905, 915 (1955).

28 Note, Two Years With the Cahan Rule, 9 Stan. L. REv. 515, 537 (1957).

29 Traynor, supra note 9 , at 336.

30 People v. Cahan, 44 Cal. 2d 434, 450, 282 P.2d 905, 915 (1955). 
Chief Justice Traynor has discussed relevant federal material in every important case, he has not failed to subject a proposed rule built on a federal model to the twin tests of purpose and practicality.

Federal cases have refused to permit a defendant to object to the admission of evidence taken in violation of the constitutional rights of someone other than himself. According to these federal cases, the defendant's constitutional rights to privacy or property have not been invaded, and therefore, he is not the proper person to raise the constitutional issues. This approach, Justice Traynor thought, was based upon an erroneous notion that the exclusionary rule was grounded in the desire to provide a remedy for wrongful misconduct toward the defendant. .1 $^{31}$ On the contrary, the purpose of the rule, "is to deter lawless enforcement of the law." The rule recognizes that government should not profit from its own wrong. If a defendant is unable to object to evidence illegally taken from a third person, the deterrent of the exclusionary rule is "to that extent nullified." If the evidence is used, the courts "virtually invite law enforcement officers to violate the rights of third persons."

Opinions of Chief Justice Traynor have recognized the right of policemen to stop and question persons whose conduct suggests that some unlawful activity is being carried out or is contemplated.

In this state, however, we have consistently held that circumstances short of probable cause to make an arrest may still justify an officer's stopping pedestrians or notorists on the streets for questioning. If the circumstances warrant it, he may in self protection request a suspect to alight from an automobile or to submit to a superficial search for concealed weapons. Should the investigation then reveal probable cause to make an arrest, the officer may arrest the suspect and conduct a reasonable incidental search. ${ }^{32}$

In contrast, the United States Supreme Court case which speaks to the "stop and question" problem seems to equate any interference with the freedom of movement with an arrest and hence forbids the interference unless grounds for arrest are present. ${ }^{33} M a p p v$. Ohio, holding that the fourth amendinent's text is applicable to the states, ultimately presents the issue whether California is free to differ from this federal standard, a standard more restrictive of police conduct than the California rule. Chief Justice Traynor has answered the question in the affirmative. He argnes that the federal "stop and question" rule is not rooted in the Constitution, but is merely a judge-made formulation necessary to the decision of a ques-

31 People v. Martin, 45 Cal. 2d 755, 290 P.2d 855 (1955).

32 People v. Mickelson, 59 Cal. 2d 448, 450-51, 380 P.2d 658, 660 (1963).

33 Henry v. United States, 361 U.S. 98 (1959). The estimate of the text may well be incorrect; Justice Traynor, however, read the Henry case that way in Mickelson. 
tion concerning which Congress had given no Legislative guidance. "Given this absence of legislation, the court had to articulate the governing rule and enforce compliance with it. It did not foreclose Congress or the states from articulating other reasonable rules consistent with the Fourth Amendment." ${ }^{\text {34 }}$

In point of fact, the Supreme Court's searches and seizures opinions have usually been drafted on the assumptions that the result in each case flows from the fourth amendment. In Chief Justice Traynor's view it would be a mistake for the Supreme Court to continue with this logic. He invites the Higl Court to formulate rubrics for the federal courts and the federal police, but to permit the states freedom of experimentation with different rules, albeit rules "consistent with the Fourth Amendment."

We know that the California "stop and question" rule is designed to permit "reasonable" police investigation of suspicious persons and circumstances on the streets. Yet the "circumstances short of probable cause" have not been defined. How short? The opinions give us some examples but no satisfactory standard. "There is," Chief Justice Traynor has written, "nothing unreasonable in an officer's questioning persons outdoors at night." ${ }^{35}$ Of course, an officer may put questions to anyone on the street at any time, but may lie interrupt movement by the use of his authority? If so, under what circumstances? A late hour, coupled with "unusual conduct" on the part of the occupants of a taxicab was held sufficient to justify a police order that the occupants get out of the cab for questioning. ${ }^{36}$ At another point it was said that "the presence of two men in a parked automobile on a lover's lane at night was itself reasonable cause for police investigation."

In the latter case, Justice Carter, in a cry of protest, said that the arrest "reminds one of the Gestapo." Surely Justice Carter's response is too sharp. Chief Justice Traynor has recognized himitations upon on-thestreet questioming. He refused to approve a search which an officer sought to justify because 'he 'didn't feel' that a person on the street at night had any lawful business there." ${ }^{\prime 38}$ The test is not, then, the officer's subjective feeling that something is in the wind.

If questioning does not produce a ground for arrest, a search more extensive than a "frisk" is not permitted. Such a search exceeds "the bounds of reasonable investigation." ${ }^{30}$ Yet we are lacking a statement

34 People v. Mickelson, 59 Cal. 2d 448, 452, 380 P.2d 658, 661 (1963).

35 People v. Simon, 45 Cal. 2d 645, 650, 290 P.2d 531, 534 (1955).

36 People v. Blodgett, 46 Cal. 2d 114, 293 P.2d 57 (1956).

37 People v. Martin, 46 Cal. 2d 106, 108, 293 P.2d 52, 53 (1956).

88 People v. Simon, 45 Cal. 2d 645, 648, 290 P.2d 531, 535 (1955).

39 People v. Mickelson, 59 Cal. 2d 448, 454, 380 P.2d 658, 662 (1963). According to People v. Haven, 59 Cal. 2d 713, 381 P.2d 927 (1963) the arrest of a defendant at a home 
which articulates the relevant factors which would guide the police. Perhaps time and the case law will conspire to perfect a formulation. It is a task that needs to be done.

Chief Justice Traynor has said that the rule permitting temporary detention for questioning "strikes a balance between a person's interest in iminunity from police interference and the community's interest in law enforcement." The "balancing of interests" is a Traynor tool which is often employed.

Chief Justice Traynor's post-Cahan opinions have indicated a respect for the privacy of the home. Unless a search incident to a valid arrest is made, the privacy of a home cannot be invaded without a search warrant or without the freely given consent of the occupant. ${ }^{41}$ There is a right to seek interviews with suspects in their home, but it does not include a right to demand that a suspect open his door. A personal association between a suspect and a known criminal is not reasonable cause for arrest, and hence, entrance to a home in order to question the suspect or to search the premises is not permitted. ${ }^{42}$

A valid consent to the search of a home is not quickly recognized. Here too, the result is explained as a matter of balance. "The rule that permits a search without a warrant only when it is incidental to a lawful arrest on the premises strikes a balance between the community's interest in law enforcement and its interest in preserving the privacy of homes." ${ }^{34}$ An arrested person who tells officers, "All right, go ahead," when they ask to enter his apartment has not given a consent untainted by coercion.44 Police authority, rather than personal choice, has moved the householder who coinplies with a policeman's demand, "Open the door right now."45

The trouble with "balancing" competing interests is that the scales are not hikely to be loaded in the same way by two judges. A judge who believes that tribunals should, in general, be ruled by pre-existing legal

does not justify the search of a hotel room some distance from the place of arrest. Haven also teaches that a search is unlawful if it has been arranged by mampulating an investigatory situation in such a way that the defendant's arrest occurs in precisely the place the police wish to search. In one view of the facts of Haven the defendant had accompanied the police to the hotel room which the police wished to search. The police arrested Haven upon arrival at the hotel and proceeded with a search.

40 People v. Mickelson, 59 Cal, 2d 448, 380 P.2d 658, 30 Cal. Rptr. 18 (1963).

41 People v. Gorg, 45 Cal. 2d 776, 291 P.2d 469 (1955). In Gorg a search of the quarters of a law student who did some gardening for the owner of the lome was upheld. The owner had consented and the officers believed this consent to be sufficient. The police had acted in good faith, therefore, according to Justice Traynor, no deterrent purpose would be served by refusing to admit the evidence taken.

42 People v. Shelton, 60 Cal. 2d 740, 388 P.2d 665 (1964).

43 Id. at 747, 388 P.2d at 669.

44 Castenada v. Superior Court, 59 Cal. 2d 439, 380 P.2d 641 (1963).

45 People v. Shelton, 60 Cal. 2d 740, 388 P.2d 655 (1964). 
material will be less enthusiastic about such a test than one such as Chief Justice Traynor who has insisted upon the importance of a judge's creative role.

The post-Cahan opinions of Chief Justice Traynor have shown a readiness to justify an arrest on a relatively small amount of incriminatory information. For example, while the tip of an anonymous informer will not provide the basis for a valid arrest, such a tip is sufficient if it is verified either by prior dealing with the unknown informant ${ }^{40}$ or by the observed conduct of the arrested person. An example of the latter sort of verification is found in Willson v. Superior Court ${ }^{47}$ when an anonymous voice over the telephone had asserted that the defendant waitress was a bookmaker. Slie was found in the place of her employment standing near the teleplione with a scratch pad in her hand. "Although petitioner's conduct . . . would not of itself constitute reasonable cause to believe she was committing a felony, it was sufficient to justify Officer Sunday's reliance on the information given her of petitioner's bookmaking." ${ }^{48}$

Another intellectual tool of Chief Justice Traynor, as we have seen, is to test proposed rules with reference to their purpose.

Statutes in almost every state permit an arrest for a felony when the person arrested is, in fact, guilty. Under these statutes an officer has not violated the law by arresting a guilty person without any reason whatsoever. These statutes have not been tested on constitutional grounds. To say the least, the seizure of a person without any information justifying it raises serious doubts whether the action violates the fourth amendment or its counterpart in the states. Whatever the ultimate decision in respect to the power of arrest, Chief Justice Traynor's opinion in People v. $B r o w n^{4 \theta}$ holds that a search incident to such an arrest is "unreasonable." To accept the contrary conclusion "would defeat the purpose of the constitutional provisions prohibiting unreasonable searches and seizures and destroy the efficacy of the exclusionary rule. In many felonies prosecuting officers would be free to arrest and search anyone, however iunocent, in the hope that the search would justify the arrest." "50

The Traynor opinion in People v. Simon ${ }^{51}$ probably represents another departure from the federal law. The Simon opinion declares that a search may take place before an arrest if there are grounds for the arrest when

46 People v. Prewitt, 52 Cal. 2d 330, 341 P.2d 1 (1959). See also People v. Boyles, 45 Cal. 2d 652, 290 P.2d 535 (1955).

4746 Cal. 2d 291, 294 P.2d 36 (1956).

48 Id. at 295, 294 P.2d at 39.

4945 Cal. 2d 640, 290 P.2d 528 (1955).

$50 I d$. at 644,290 P.2d at 530 .

5145 Cal. 2d 645,290 P.2d 531. 
the search was begun. No purpose is served by the federal rule. There is nothing unreasonable about searching first and arresting later.

In fact, if the person searched is innocent and the search convinces the officer that his reasonable belief to the contrary is erroneous, it is to the advantage of the person searched to not be arrested. On the other hand, if he is not innocent or the search does not establish his innocence, the security of his person, house, papers, or effects suffers no more from a search preceding his arrest than it would from the same search following it. In either case the important considerations are whether the officer had reasonable cause before the search to make an arrest and whether the search and any seizures incident thereto were or were not more extensive than would reasonably be justified as incident to an arrest. ${ }^{52}$

Another open question after Cahan was whether a criminal conviction can be collaterally attacked if it had been brought about by illegally obtained evidence. A consideration of the purpose of the exclusionary evidence rule laid the issue to rest for Chief Justice Traynor. ${ }^{53}$ The case presented a conflict between the policy "in favor of finality of judgments and the policies to discourage lawless enforcement of the law." "Since," he went on to say, "the latter policy may be adequately protected at trial and on appeal, it need not be further promoted by destroying the finality of judgments."

Justice Traynor's attention to the fundamental purpose of the exclusionary rule has also led him to decide that the admission of illegally obtained evidence which is "merely cumulative of other undisputed evidence in the record" is not a ground for reversing a conviction. ${ }^{55}$ Chief Justice Traynor distinguishes the confessions cases in which he does not recogmize a doctrine of harmless error. Confessions almost invariably are persuasive evidence of guilt, and it would be "extremely difficult" to determine the part that a confession plays in securing a conviction..$^{56}$ However, "other illegally obtained evidence may be only a relatively insigmificant part of the total evidence and have no effect on the outcome of the trial." ${ }^{357}$ To reverse automatically is to lose sight of the basic purpose of the exclusionary rule: the deterrent effect on

62 Id. at $648,290 \mathrm{P} .2 \mathrm{~d}$ at 533 .

53 In re Harris, 56 Cal. 2d 879, 880, 366 P.2d 305, 306 (1961). Traynor, J. concurring. 54 Id. at 885,366 P.2d at 309.

55 People v. Parham, 60 Cal. 2d 378, 384, 384 P.2d 1001, 1005 (1963). Cf. Justice Traynor's dissent in People v. Tarantino, 45 Cal. 2d 590, 602, 290 P.2d 505, 513 (1955) in which he votes to forbid the use of illegally obtained evidence which was "intermixed" with the other irrelevant evidence.

56 People v. Parham, 60 Cal. 2d 378, 384 P.2d 1001 (1963).

57 Id. at 387, 384 P.2d at 1005. See People v. Mattesen, 61 Cal. 2d 511, 393 P.2d 161 (1964). The introduction into evidence of defendant's involuntary incriminating statement was held reversible error without any consideration of the part the statement may have played in obtaining the conviction. 
police misconduct. Indeed, automatic reversals for harmless errors would but generate pressure to undermine constitutional standards of police conduct. Courts would stretch to judge the conduct lawful so that needless retrials could be avoided.

Chief Justice Traynor's commitment to interpreting a rule in accordance with its purpose lias led him to change another traditional common law rule of evidence. The common law rule forbidding the admission into evidence of coerced confessions was himited to declarations which were affirmations of guilt. The rule did not apply to incriminatory statements which fell short of a complete admission of criminality. This distinction was obliterated by a Traynor opinion in consideration of the purpose of the rule banning coerced confessions. ${ }^{58}$

Involuntary confessions are excluded because they are untrustworthy, because it offends "the community's sense of fair play, and decency" to convict a defendant by evidence extorted from his, and because exclusion serves to discourage the use of physical brutality and other undue pressures in questioning those suspected of crime.... All these reasons for excluding involuntary confessions apply to involuntary admissions as well. ${ }^{50}$

\section{III}

CONFESSIONS AND THE RIGHT TO COUNSEL

People v. Garner, ${ }^{80}$ Justice McComb writing the opinion of the court, holds that to admit into evidence a voluntary confession made outside the presence of counsel but after the lodging of a formal charge denied neither the right to counsel nor the right to due process of law. Justice Traynor concurred, but set forth his own reasons. ${ }^{01}$ The New York cases on which the defendant relied, "must be considered in some detail since they present some of the practical considerations relevant to the solution of the constitutional problem." ${ }^{32} \mathrm{He}$ saw those opinions as permitting police questioning in a "neutral inquiry," but forbidding the "interrogation of a person suspected of commiting the crime." distinction, he argued, cannot turn on whether an indictment has been voted. Suspicion of a most serious sort might fall upon the defendant before the formal charge. If this distinction is to be read into the due process clause, it ought to forbid questioning without counsel as soon as the police have decided that the defendant is the person to be charged.

58 People v. Atchley, 53 Cal. 2d 160, 346 P.2d 764 (1959).

59 Id. at $170,346 \mathrm{P} .2 \mathrm{~d}$ at 769.

6057 Cal. 2d 135, 367 P.2d 680 (1961).

61 Id. at 156, 367 P.2d 680 (1961).

62 Id. at 158,367 P.2d at 693 .

${ }^{63} I d$. at 161-62, 367 P.2d at 696 . 
The restriction on police interrogation opportunities would be great and place an immense burden on the police. Questioning is "often essential to the solution of a crime and the confession of the guilty," ern scientific police work. The perpetrator of a crime knows most about the event, and his confession is the best evidence of guilt. Only the most important social policies can justify exclusion such as a policy against outrageous police methods. Further, there is a compulsion to confess, and presunably it is absurd for the law to make such confessing impossible. The lawyer, present during the questioning period would not limit himself to the prevention of the third degree or to an explanation of the legal siguificance of the questions, but the lawyer would invoke the right to silence at an early time in a great many cases.

Left to himself, Chief Justice Traynor would not import the neutral inquiry-suspicion distinction into the fourteenth amendment. The right to counsel is adequately protected in California but it "does not imply ... that a defendant lawfully in custody must be insulated from the police." ${ }^{\prime 65}$ The remedy for abuse in questioning is the rule excluding involuntary confessions. A final practical point is made against the contrary rule. If persons who are able to retain counsel are entitled to presence of a lawyer during questioning, indigent persons or those without the foresight to retain counsel must be provided the same advantage through assignment or there would be a "widening of the gulf between the rights of a person with and one without counsel."

It often happens that state justices are not left to themselves. In the October 1963 term, the Supreme Court of the United States decided Escobedo v. Illinois ${ }^{66}$ and Massiah v. United States. ${ }^{67}$ Taken together, they can be read as holding that a suspect's right to counsel begins as soon as the police process shifts from investigation to accusation; as soon as the person questioned is no longer simply one who "knows something" or one who "might be involved," but the actual accused in the eyes of the police.

Faced with these cases, the Supreme Court of California shifted its ground from Garner. People v. Dorado ${ }^{68}$ holds that in situations similar to Massiah and Escobedo, the authorities may not carry out a process of interrogation which invites incriminating statements unless the suspect

64 Ibid.

$65 I d$. at 166,367 P.2d at 699 .

66378 U.S. 478 (1964).

67377 U.S. 201 (1964).

68 The original opinion in People v. Dorado, 61 A.C. 892, 394 P.2d 952, 40 Cal. Rptx. 264 (1964), was vacated when the California Supreme Court granted a rehearing. The opinion of the court on rehearing was substantially the same as the vacated opinion. See 62 A.C. 350 (Jan. 29, 1965). 
has been told of his right to remain silent and of his right to have the advice of counsel.

Though Chief Justice Traynor did not write in Dorado, he voted with the majority and subscribed to the opinion of the court. We cannot, of course, hold him to the language of Justice Tobriner's opinion. However, in matters relating to the interpretation of the Constitution of the United States, Chief Justice Traynor has habitually followed the decisions of the United States Supreme Court in a liberal fashion. He is not a judge who takes restricted and limited readings of high court opinions simply because he dislikes them. Dorado is a case in point. There the Chief Justice associates himself with an opinion which is at variance with his own views expressed in Garner because these views have been superceded by the law of the land.

\section{IV}

THE RIGHT TO APPOINTED COUNSEL

Indigent defendants in state felony cases are entitled to state-supplied counsel under a recent United States Supreme Court opinion, Gideon v. Wainveright. ${ }^{69}$ We can predict that hitigation in the near future will often raise questions concerning the adequacy of assigned counsel.

The general rule today is that a defendant has no right to attack a conviction unless his lawyer's lack of dedication or competence has reduced a trial to a "farce or a sham." In People v. Ibarra, ${ }^{70}$ Chief Justice Traynor was concerned with a defense lawyer who was deficient in knowledge. The deputy public defender did not know about the California rule which permits a defendant to challenge the legality of a search although he also denies that heroin was taken from him and that he has any proprietary interest in the premises entered. The rule was said to be "commonplace to any attorney engaged in criminal trials." It had been articulated in several important California cases and was readily to be found in standard reference works. Ibarra did not present a case of poor tactical judgment, but of a failure of preparation.

Counsel's failure to research the applicable law precluded the exercise of judgment on his part and deprived defendant of an adjudication of what was clearly the stronger of the two defenses available to him .... Counsel's statement to the court makes perfectly clear that his decision reflected, not judgment, but unawareness of a rule of law basic to the case; a rule that reasonable preparation would have revealed. Counsel's failure to object precluded resolution of the crucial factual issues supporting defendant's primary defense. It thereby reduced his trial to a farce and a sham. ${ }^{71}$ 
The Traynor opinion, if its reasoning is widely adopted, could have the most far reaching consequences. In inany states, inexperienced lawyers are generally asked to undertake the defense of the poor. Many defendants will be retried if we adopt the principle that what a lawyer does not know shall not hurt his client.

Does a criminal defendant have a right to counsel on appeal and, if so, in what circumstances? Under the California system which prevailed until recently a convicted defendant was given counsel on appeal only after the district court of appeal had made an independent investigation of the record and determined that there was merit in the request for review. According to Justice Traynor's concurring opinion in People v. $B$ Brown ${ }^{72}$ (later vindicated by the Supreme Court of the United States), ${ }^{73}$ the California system violated the United States Supreme Court's decision in Griffin v. Illinois ${ }^{74}$ on the ground that the systein created an invidious discrimination against indigent defendants because of their poverty. Persons of wealth can have the benefit of lawyers to argue their appeals; persons without means are provided with counsel only after a court's judgInent that the record reveals some point of merit.

Chief Justice Traynor, lowever, called for a change in California law on other than constitutional grounds. A defendant without a lawyer cannot ordinarily obtain a proper record on appeal. A concern for the proper functioning of appellate courts argues for the appointment of counsel. Time and trouble will be avoided by the help of the legal experts. The court as well as the defendant will benefit from oral argument and briefs by counsel.

This is a convenient point at which to digress and to note a characteristic of many Traynor opinions. He often expresses views in order to instruct us even though instruction is not required to decide the issue before him. In Brown, he wrote a concurring opinion on matters not necessary to the decision of the case. "The question calls for resolution even though we appointed counsel to represent the defendant in this court."75 The Justice not only indicated that counsel should always be appointed, but went on to himit his proposed rule to felony cases. Misdemeanors are circumstantially less serious. No loss of civil rights is involved. The misdemeanant has an absolute right to bail; his incarceration will be brief; the judge may permit the misdemeanant to serve his time outside working hours, therefore he may be able to employ counsel. Furthermore, we learn that his proposal would only provide lawyers to make the first appeal. "The reasons for this appointment of counsel on

7255 Cal. 2d 64, 357 P.2d 1072 (1960).

73 See Douglas v. California, 372 U.S. 353 (1963).

74351 U.S. 12 (1955).

75 People v. Brown, 55 Cal. 2d 64, 70, 357 P.2d 1072, 1076 (1960). 
appeal from judgments of conviction do not extend to habeas corpus or other collateral attacks on final judgments or convictions unless the defendant presents a prima facie case for rehef."

Frivolous appeals at state expense can be avoided by the lawyer appointed to handle the appeal. In another opinion, In re $\mathrm{Nash}^{77}$ the defendant complained that he was denied effective representation of counsel on appeal because his appointed counsel had informed the court that he could find no meritorious ground for appeal, and hence, he had refused to argue the case or present a brief. The defendant relied upon the United States Supreme Court's Douglas v. California, ${ }^{78}$ in which the Court had declared unconstitutional the system of providing counsel on appeal which had been discussed by Justice Traynor in People v. Brown.

Chief Justice Traynor's opinion in Nash rules against the defendant. Some practical way must be found to hmit useless appeals. The present California system of leaving the decision respecting merit to an attorney engaged as an advocate for the defendant offers a satisfactory compromise. "Admittedly, it does not insure exact equahty between indigent defendants and those who have ample funds to retain counsel. . . ." The rich can still take frivolous appeals but "exact equality is impossible to attain." The Douglas case only forbade "invidious discrimination."

$\mathrm{V}$

\section{DISCOVERY}

Few states lave gone so far toward liberalizing the criminal discovery rules as has California. The liberalization is a relatively recent development which began with a Traynor opinion, People v. Riser, ${ }^{80}$ in 1956. Although this case dealt solely with the question whether a defendant may have discovery of a statement made to the prosecutor after the maker of the statement had testified at the trial, the reasoning of the opinion was by no means restricted to such a narrow problem.

Absent some governmental requirement that information be kept confidential for the purposes of effective law enforcement, the state has no interest in denying the accused access to all evidence that can throw light on issues in the case, and in particular it has no interest in convicting on the testimony of witnesses who have not been as rigorously cross-examined and as thoroughly impeached as the evidence permits. To deny flatly any right of production on the ground that an imbalance would be created between the advantages of prosecution and 
defense would be to lose sight of the true purpose of a criminal trial, the ascertainment of facts. ${ }^{81}$

Marching from People v. Riser there has been a parade of cases, under which

defendants are entitled to pretrial discovery of the names and addresses of witnesses, photographs, results of scientific and other investigations, and statements to the police by defendants or witnesses, whether or not the statements are signed or acknowledged. The defendant need not claim ignorance of the facts; he need claim only ignorance of the contents of the statements or the details of the materials he seeks to inspect. He need not show that the material sought will be admissible into evidence; he need show only that it may aid him in the ascertainment of the facts. If necessary, he may also obtain an order that the prosecution refrain from interfering with defense counsel's right to seek interviews with witnesses. ${ }^{82}$

Against the background of this California development, Chief Justice Traynor has written an opinion of fundamental importance, Jones $v$. Superior Court, ${ }^{83} \mathrm{~m}$ which the prosecution was given discovery rights against the defendant, a right generally demied because of the defendant's privilege against self-incrimination.

In Jones the defendant sought a continuance to establish his defense against a charge of rape. He alleged that he had been impotent for years and needed time to gather medical evidence in connection with injuries he had suffered some years before the trial. When the motion was granted, the district attorney requested that the petitioner make available to the prosecution the names and addresses of the doctors who had been subpoenaed to testify, those who had treated the petitioner prior to trial, all medical reports bearing on the question of impotency, and all $\mathrm{X}$-rays relating to the injury.

The claim must have struck a sympathetic note to Chief Justice Traynor because he has written that a spirited defense of the adversary system is "hardly realistic unless the evidence is accessible to the adversary in advance so that each can prepare accordingly in the light of such evidence. ${ }^{384}$ However, the prosecutor's request troubled him because under the self-incrimination privilege a defendant may not be required to produce private documents nor assist the prosecution in preparing the case against him.

Chief Justice Traynor found a practical resolution of the issue

$81 \mathrm{Id}$. at 586, $305 \mathrm{P} .2 \mathrm{~d}$ at 13.

82 Traynor, Ground Lost and Found in Criminal Discovery, 39 N.Y.U. L. REv. 228, 244 (1964).

8358 Cal. 2d 56, 372 P.2d 919 (1962).

84 Id. at 62,372 P.2d 919, 922 (1962). 
presented by the district attorney's request. The defendant was required to list the names of witnesses lie intended to call at the trial and to disclose reports and $\mathrm{X}$-rays he intended to place in evidence. An analogy was found in those statutes which permit or require pre-trial discovery if alibi or insamity are to be the ground for a defense. These statutes have been sustamed against the claim that they violate the self-incrimination privilege. The requirement laid down by the California court in Jones was simply a reasonable and practical procedural step. It advances the time when the defendant must show that wlich he plans to reveal, but it does not compel him to disgorge anything which he wishes to keep hidden. "It simply requires petitioner to disclose information that lie will shortly reveal anyway." 85

\section{CONCLUSION}

Some of Chief Justice Traynor's most distinguisled judicial work has been in relation to the administration of criminal justice. He has not copied the precedents but las cut new paths by asking questions: What is this rule to do? What considerations of policy are involved in this case? What can we do that is just, fair, and practical?

His way of working asks help from the present rather than the past. The facts of today are more helpful than the authority of yesterday. He has asked the lawyers and the scholars to help the judges with constructive lawyering and creative proposals.

In his lectures the Chief Justice has referred frequently to a sense of the turbulence of life and the desperate way in which courts and judges must impose order on it. "Out of the new day's commotion whirl competing interests that may spend some of their violence but none of their force by the time they near the courtroom." 8

A judge, Chief Justice Traynor has written,

can no longer invoke with assurance the nearest quieting precedent. The nearest analogy may seem to him only impertinent. Tried and half-true formulas will not serve hin, for all their show of stability. He must coinpose his own mind as he leaves antiquated compositions aside to create some fragments of legal order out of disordered masses of new data. There should be modern ways for such a task, in fairness not only to him but to those who must seek out his judgment and abide by his decisions. ${ }^{87}$

The high quality of the "fragments of legal order" which have come from his reflections move us to lonor him and to commend his example to others.

85 Id. at 62,372 P.2d at 923.

80 Traynor, supra note 82 , at 228 .

87 Traynor, Better Days in Court for a New Day's Problem, 17 VAND L. REv. 109 (1963). 